\title{
Vi trenger sterkere samarbeid Om behovet for koordinering av genetisk epidemiologisk forskning i Norge
}

\author{
Camilla Stoltenberg \\ Divisjon for epidemiologi, Nasjonalt folkehelseinstitutt, Postboks 4404 Nydalen, 0403 Oslo
}

\section{DEN INTERNASJONALE UTFORDRINGEN}

Befolkningsbaserte data er et av Norges fremste forskningsmessige fortrinn. I kjølvannet av molekylærbiologien har interessen for epidemiologiske data økt enormt i løpet av de siste fem årene. Den store interessen gir gode muligheter for utvikling og finansiering av viktige studier, men den gir også økt konkurranse om tilgang til data, og fare for at sterke aktører internasjonalt skal dominere feltet uten at norsk forskning får glede av det fortrinn vi nå har.

Mye god og viktig epidemiologisk forskning berøres i liten grad av den molekylærgenetiske utviklingen. Mange spennende studier krever lite samarbeid og liten eller ingen nasjonal koordinering. Ganske annerledes er det når vi driver store og langvarige kohortstudier som blant annet involverer drift av biobanker med dyre analyser som scanning av hele genomet til flere hundre tusen deltakere eller genekspresjon, rift om tilgang til de biologiske prøvene og mulige kommersielle interesser. Slik virksomhet krever et godt organisert nasjonalt samarbeid og funksjonsdeling mellom forskningsinstitusjoner og regioner.

Hvis vi skal utvikle og utnytte våre fortrinn bør vi benytte muligheten nå. En rekke land er i ferd med å bygge opp store befolkningsbaserte databaser med helseopplysninger og biologiske prøver. Samtlige tar sikte på å studere de genetiske/biologiske og miljømessige årsakene til vanlige sykdommer som hjerteinfarkt, kreft og psykiatriske lidelser.

For å illustrere satsingen vi står overfor internasjonalt er det interessant å se på det som skjer i Storbritannia. Et av de mest ambisiøse forsøkene på å etablere en stor befolkningsundersøkelse planlegges under navnet BiobankUK. BiobankUK tar sikte på å samle opplysninger og blodprøver fra 500000 voksne personer mellom 45 og 69 år i løpet av perioden 2003-2008. Planleggingen av prosjektet har pågått i mer enn 3 år. I april 2002 fikk prosjektet 45 millioner pund, det vil si mer enn 500 millioner NOK, i støtte fra det uavhengige Wellcome Trust, det britiske medisinske forskningsrådet (MRC) og det britiske helsedepartementet for å studere gener, miljø og helse. Andre eksempler på at det bygges opp store befolkningsbaserte helsedatabaser og biobanker til studier av gener, miljø og helse finnes blant annet i Sverige, Danmark, Finland og Island. Både EU og National Institutes of Health (NIH) i USA viser stor interesse for denne type data. Bare i løpet av høsten 2002 skal det arrangeres minst fem ulike internasjonale møter om slike studier.

\section{FORSLAG TIL MÅL FOR GENETISK EPIDEMIO- LOGISK FORSKNING I NORGE}

Norsk epidemiologi bør ha som mål

- å bygge opp en nasjonal helsedatabase med tilhørende biobank i samme størrelsesorden som den britiske

- å ha denne databasen klar til bruk i vitenskapelige prosjekter fra 2006

- utvikle noen få, det vil si maksimalt 5 , gode prosjekter knyttet til enkeltsykdommer som vi samarbeider om nasjonalt

Utfordringen til norsk epidemiologi er å få til et nasjonalt samarbeid og en arbeidsdeling som gjør oss i stand til å delta $\mathrm{i}$ fronten i den internasjonale utviklingen innenfor den genetiske epidemiologien og den delen av funksjonell genomforskning som tar utgangspunkt i epidemiologiske data. Dette er kostbart og det krever meget høy kompetanse.

\section{EKSISTERENDE SAMARBEID}

De epidemiologiske miljøene i Norge samarbeider allerede om datainnsamling $i$ de regionale helseundersøkelsene og om en rekke prosjekter. De nye teknologiske mulighetene, den vitenskapelige verdien av store befolkningsundersøkelser, kravene til kvalitet, mangelen på kompetente fagfolk innenfor blant annet statistikk og bioinformatikk, og behovet for sterkere finansiering, taler for at vi bør satse på et økt nasjonalt samarbeid. På enkelte områder bør vi også bli enige om en arbeidsdeling for å unngå å spre knappe ressurser. Dette krever organisasjon, ledelse og felles retningslinjer. Samarbeidet må være slik at alle parter er tjent med det.

\section{HVA BØR DANNE GRUNNLAGET FOR ET ØKT NASJONALT SAMARBEID?}

Prosjektene som egner seg som grunnlag for et $ø k t$ nasjonalt samarbeid innenfor epidemiologisk forskning $i$ årene framover er CONOR og Den norske mor og barn undersøkelsen.

\section{CONOR}

Det største og viktigste eksisterende nasjonale samarbeidsprosjektet er Cohort of Norway (CONOR). CONOR er et forskningssamarbeid mellom de epidemiologiske miljøene ved universitetene og Nasjonalt folkehelseinstitutt. Målet er å samle inn helsedata og 
blodprøver fra 200000 voksne personer for å forstå årsaker til sykdom. Det er hittil samlet inn data og blodprøver fra ca. 175000 individer, og 200000 vil sannsynligvis nås i 2003.

CONOR benytter et felles sett av spørsmål som inngår $\mathrm{i}$ de regionale helseundersøkelsene $\mathrm{i}$ Tromsø (Tromsø IV, i regi av Universitetet i Tromsø), NordTrøndelag (HUNT II, nå i regi av NTNU), Hordaland (HUSK, i regi av Universitetet i Bergen), Oslo (HUBRO, i regi av Oslo kommune, Folkehelseinstituttet og Universitetet i Oslo), Oppland og Hedmark (OPPHED, nå i regi av Folkehelseinstituttet), Troms og Finmark (TROFINN, nå i regi av Folkehelseinstituttet) og i den planlagte helseundersøkelsen i områder med samisk bosetting (Universitetet i Tromsø og Senter for samisk helseforskning). Gjennom det nasjonale apparatet for helseundersøkelser som tidligere fantes i Statens helseundersøkelser, står Folkehelseinstituttet for den vesentlige delen av datainnsamlingen $i$ alle disse undersøkelsene. Helseundersøkelsene avsetter en del av blodprøvene (fullblod eller koagler) til CONOR og fryser dette ned lokalt eller i Folkehelseinstituttet. CONOR vil gi opplysninger om risikofaktorer, miljøeksponeringer og biologiske (inkludert genetiske) forhold som kan måles i blodet. Opplysninger om senere sykdom eller død hos deltagerne skal hentes fra sykdomsregistre (blant annet Kreftregisteret), Dødsårsaksregisteret og egne datainnsamlinger for å skaffe informasjon om hvordan det går med deltagerne (endepunkter).

Helsedepartementet utnevner CONORs styringsgruppe som har representanter fra helseundersøkelsene i Nord-Trøndelag (HUNT), Hordaland (HUSK), Tromsø (Tromsøundersøkelsene) og Oslo (HUBRO), samt en leder og sekretær fra Folkehelseinstituttet.

CONOR kan besvare viktige spørsmål om utbredelsen av vanlige plager og sykdommer i Norge. Muligheten for å studere relativt sjeldne eksponeringer og sykdommer, samt undergrupper av risikofaktorer og sykdommer, gjør CONOR spesielt verdifullt. Materialet er reservert for problemstillinger som ikke kan besvares i de regionale undersøkelsene, men krever større befolkninger. Det er foreløpig ikke satt i gang noen spesifikke prosjekter i CONOR, men den første datafilen var klar for analyse i juni 2002. CONOR har ingen egen finansiering.

\section{Den norske mor og barn undersokelsen}

Den norske mor og barn undersøkelsen drives av Folkehelseinstituttet i Bergen (Medisinsk fødselsregister) og Oslo. Studien inviterer gravide kvinner til å delta $\mathrm{i}$ forbindelse med at de møter til første ultralyd i svangerskapet (ca. uke 17). Kvinnens partner inviteres også til deltagelse, og kvinnen gir samtykke til at barnet skal delta etter fødselen og fram til 18 års alder. Det er nå ca. 15000 kvinner som deltar. Studien tar sikte på å rekruttere 100000 mødre, deres ca. 100000 barn, og omkring 70000 fedre innen utgangen av 2005. Studien har mottatt 5 millioner NOK over stats- budsjettet årlig, men har ingen sikker finansiering. Det er en rekke delprosjekter knyttet til studien som bidrar med finansieringen. Tre av disse er internasjonale samarbeidsprosjekter som omfatter søknader til NIH i USA.

Mor og barn undersøkelsen er den største epidemiologiske studien som drives i Norge. Delprosjektene involverer en rekke kliniske miljøer og samfunnsmedisinske miljøer. Målet er å involvere basalmedisinske miljøer, informatikk/bioinformatikk og filosofi/etikkmiljøer ved universitetene i tillegg. Studien er nylig omorganisert og det er vedtatt å opprette et fagråd med representasjon fra samtlige av universitetene, og andre samarbeidspartnere som Kreftregisteret og Helseregionene.

\section{FUGE}

Folkehelseinstituttet sendte i samarbeid med styringsgruppen i CONOR en søknad til FUGE-programmet som har fått støtte (i størrelsesorden 10 millioner NOK per år i 5 år). Søknaden beskriver oppbygging av en plattform basert på helsedata og blodprøver fra CONOR og Mor og barn undersøkelsen, det vil si totalt ca. 470000 personer i Norge, samt fra enkeltprosjekter, nasjonale helseregistre og en database med informasjon om familierelasjoner (se Figur 1). Hensikten med plattformen er å danne grunnlag for prosjekter som ser på genenes funksjoner (funksjonell genomforskning). Det kan dreie seg om alt fra identifikasjon av gener, studier av samspillet mellom gener og miljø, identifikasjon av miljøfaktorer ved hjelp av risikogener, genekspresjonsstudier, og validering av enkeltgeners betydning for sykdom i befolkninger.

På grunn av størrelsen og kravene til nasjonalt samarbeid, vil FUGE-bevilgningen være et viktig utgangspunkt for økt nasjonalt samarbeid innenfor epidemiologien og for utviklingen av prosjekter i CONOR og Mor og barn undersøkelsen. Både CONOR og Mor og barn undersøkelsen har målsettinger og muligheter som omfatter langt mer enn funksjonell genomforskning, men gjennom genetisk epidemiologi og funksjonell genomforskning vil de epidemiologiske miljøene få anledning til å prøve ut samarbeid på tvers av fagmiljøer $i$ en hittil ukjent størrelsesorden. FUGEbevilgningen viser tydelig at de epidemiologiske ressursene $\mathrm{i}$ form av kompetanse, data og biologiske prøver har betydning som kilde til forskning langt utover de epidemiologiske miljøene selv.

\section{HVORFOR STYRKE SAMARBEIDET?}

Det overordnete målet med økt nasjonalt samarbeid innenfor epidemiologien er å bli bedre til å

- Beskrive sykdom, risikofaktorer og beskyttende faktorer i befolkningen

- Finne årsaker til sykdom

- Få kunnskap som kan føre til bedre behandling og forebygging av sykdom og død 


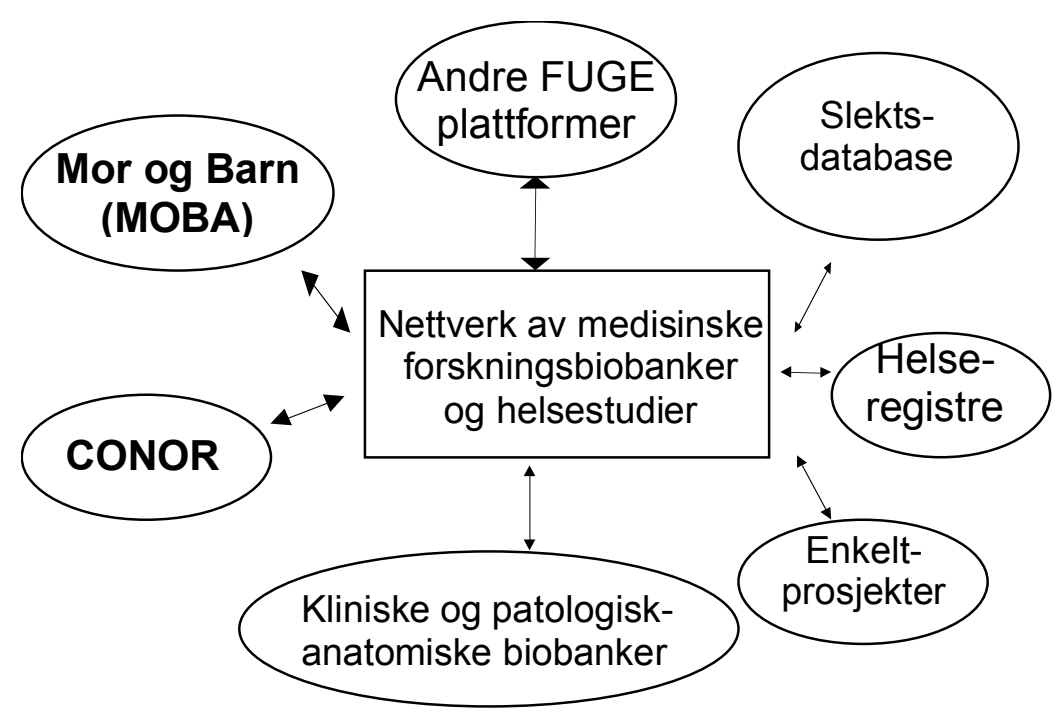

Figur 1. Skjematisk fremstilling av den såkalte FUGE-plattformen som Folkehelseinstituttet søkte støtte til i samarbeid med CONORs styringsgruppe.

For å oppnå dette trenger vi:

- Store utvalg av normalbefolkning og informasjon om pasienter innen hver sykdomskategori

- Langvarige prospektive studier

- Biologiske prøver (biobanker)

- Slektskapsdata

- Bedre og flere nasjonale sykdomsregistre, inkludert et pasientregister som kan gi opplysninger på individnivå (det vil si pseudonymt eller personidentifiserbart)

- Styrket samarbeid med andre faggrupper, blant annet innenfor statistikk, bioinformatikk, molekylærbiologi, klinisk medisin og genetikk

\section{HVORDAN STYRKE SAMARBEIDET?}

Et økt samarbeid innenfor epidemiologien bør ta utgangspunkt i data og prosjekter der nasjonalt samarbeid er nødvendig for å få tilstrekkelig kompetanse, data, utstyr og penger. Det bør konsentreres om konkrete plattformer (for eksempel CONOR og Mor og barn undersøkelsen) og spesifikke problemstillinger. Slike problemstillinger kan være knyttet til studier av nevrologiske sykdommer i samarbeid med Nevronor, studier av gener og miljø som i studien av miljøfaktorer $\mathrm{i}$ utviklingen av type 1 diabetes (MIDIA-prosjektet), samt studier av en rekke kandidatgener for så forskjellige tilstander som hjerte- og karsykdommer, osteoporose, depresjon, preeklampsi, medfødte misdannelser og for tidlig fødsel. Samarbeidet bør koordineres av Folkehelseinstituttet. Universitetene og andre samarbeidspartnere bør ha innflytelse gjennom en styringsgruppe, et styre eller et epidemiologisk fagråd.

Planlegging av helseundersøkelser (som inngår i CONOR), delprosjekter i CONOR og Mor og barn undersøkelsen, søknader nasjonalt og internasjonalt og arbeidsdeling mellom partene bør være saker for en slik styringsgruppe eller fagråd.

Norges forskningsråd bør spille en aktiv rolle i arbeidet med å utvikle et slikt samarbeid. Det bør for eksempel taes initiativ til et nasjonalt møte om

- Hva et økt nasjonalt samarbeid bør bygge på

- Hvordan det bør ledes og organiseres

- Felles retningslinjer for bruk av data og biologiske prøver

- Finansiering

\section{NØDVENDIGE FORUTSETNINGER}

Nødvendige forutsetninger for et økt nasjonalt samarbeid innenfor epidemiologien er at:

- Vi utvikler gode vitenskapelige ideer og satser på noen av dem

- Alle parter har fordeler av samarbeidet

- Alle parter er forpliktet av samarbeidet

- Regjering og Storting fortsetter å investere i helseundersøkelser, helseregistre og epidemiologisk forskning

- Stortinget vedtar lover som gjør slik epidemiologisk forskning både forsvarlig og mulig

- Vi utvikler felles regler for tilgang til data og problemstillinger

- Vi utvikler felles regler for samarbeid med industrien, kommersialisering og næringsutvikling basert på kunnskap som kommer ut av samarbeidet

- Vi styrker ledelse og organisering av store prosjekter

- Vi utvikler internasjonalt samarbeid

- Prosjektfinansieringen økes gjennom gode søknader internasjonalt og nasjonalt

- Arbeidsdeling avtales på områder der det kreves spesiell kompetanse og/eller dyrt utstyr. Vi mener ikke 
at det er nødvendig med arbeidsdeling mellom universitetene og andre forskningsinstitusjoner når det gjelder tema (for eksempel hjerte- og karsykdom, nevrologiske sykdommer osv.), men det er nødvendig å ikke konkurrere om midler til å bygge opp teknologisk kompetanse og dyre utstyrsparker parallelt ved de ulike institusjonene.

- Organisering og infrastruktur bedres slik at kapasitet frigjøres til analyse og skriving av vitenskapelige artikler hos forskerne

Folkehelseinstituttet bør ha en sentral rolle i driften og koordineringen av helseundersøkelser og andre store befolkningsbaserte studier, spesielt der det inngår bruk av biologiske prøver (biobanker). Universitetene og andre forskningsinstitusjoner bør være involvert i planlegging, prioritering av prosjekter, avtaler om arbeidsdeling, analyse og søknader. Folkehelseinstituttet bør ha egen forskning som i stor grad er prosjektfinansiert for å holde høy kvalitet på studiene.

\section{HVA HASTER MEST?}

$\varnothing k t$ nasjonalt samarbeid innenfor epidemiologien er mulig og ønskelig spesielt i tilknytning til oppbygging av en stor nasjonal helsedatabase og biobank basert på
CONOR og Den norske mor og barn undersøkelsen. På grunn av den internasjonale interessen og de nye teknologiske mulighetene bør samarbeidet nå konsentreres om genetisk epidemiologi og den delen av funksjonell genomforskning som vil benytte befolkningsbaserte data. Universitetene representert ved CONORs styringsgruppe og Folkehelseinstituttet samarbeider om dette allerede, men har behov for å utvikle vitenskapelige ideer, organisasjon og finansiering videre $\mathrm{i}$ løpet av høsten 2002 og våren 2003. NFR bør ta initiativ til et nasjonalt møte for å diskutere hvilke vitenskapelige ideer som bør prioriteres og hvordan samarbeidet bør organiseres og finansieres.

Det finnes allerede et utstrakt nasjonalt samarbeid innenfor epidemiologien som bør utvikles videre. Dette haster ikke i samme grad som økt samarbeid om genetisk epidemiologi, funksjonell genomforskning og bruk av biobanker i tilknytning til CONOR og Den norske mor og barn undersøkelsen. Vi har en gylden anledning på dette feltet. Riktige prioriteringer vil komme epidemiologien som helhet til gode.

Artikkelen bygger på uttalelsen fra Folkehelseinstituttet til NFR om økt nasjonalt samarbeid innenfor epidemiologisk forskning. 